Article

\title{
How Does Board Gender Diversity Influence the Likelihood of Becoming a UN Global Compact Signatory? The Mediating Effect of the CSR Committee
}

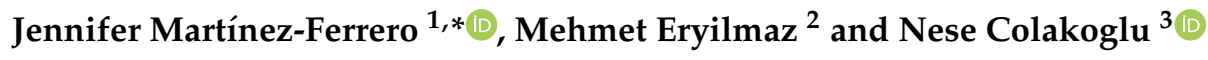 \\ 1 IME (Multidisciplinary Institute for Enterprise), Universidad de Salamanca, 37007 Salamanca, Spain \\ 2 Department of Business Administration, Faculty of Economics and Administrative Sciences, Bursa Uludag \\ University, 16059 Nilüfer, Bursa, Turkey; mehmetery@uludag.edu.tr \\ 3 Free Researcher, 16059 Bursa, Turkey; nesecolakoglu@hotmail.com \\ * Correspondence: jenny_marfe@usal.es
}

Received: 6 May 2020; Accepted: 24 May 2020; Published: 25 May 2020

\begin{abstract}
The aim of this study was to improve the understanding of the factors determining a firm's affiliation with the United Nations Global Compact (UN GC) as the largest voluntary corporate responsibility initiative worldwide. Drawing on the board perspective of the firm, this paper examines the effect of gender diversity and the mediating effect of the existence of a corporate social responsibility (CSR) committee. To test the paper's objectives, the authors use an international sample of analysis of 29,951 firm-year observations from 2012 to 2018. The results suggest that female directors on the board significantly encourage the firm's affiliation with the UN GC and support the mediating effect of the existence of a CSR committee. Therefore, the positive impact of female directors on UN GC signatories appears to be mediated by the existence of a CSR committee.
\end{abstract}

Keywords: United Nations Global Compact; board gender diversity; CSR committee

\section{Introduction}

With the increased sensitivity to better governance and social responsibilities of business organizations, particularly after having experienced corporate scandals, many corporate social responsibility (CSR) initiatives, either voluntary or mandatory, have emerged at the industry, country, and global levels, and have rapidly gained popularity. The largest of these initiatives in terms of the number of members is the United Nations Global Compact (UN GC). Although some studies [1-7] have focused on the consequences of adoption of the UN GC, and have discussed or empirically reported economic and ethical benefits for members, the literature has largely remained silent about the antecedents of adoption of the UN GC [8].

Although the UN GC has grown in popularity and shows great potential for the business world as mentioned above, the literature on the UN GC is still largely conceptual $[1,6,8-10]$ and has only attracted the attention of several researchers who have examined the determinants of this standard [11,12]. It should be noted that a limited number of studies have examined the factors influencing the firm's decision to affiliate with the UN GC [11]. In this respect, three main groups of factors affecting UN GC adoption are identified [10]: (i) the external pressures from society, activists, governments, and the level of country democracy and liberalism of the economic system [13,14]; (ii) the internal pressures related, for example, to firm size and the firm's level of CSR performance [15], or (iii) the firm financial performance and presence of firm-specific resources [16]. However, the board's influence has not been 
explored as an internal factor, despite the fact that leadership of the firm was recently identified as a fourth and distinct source of pressure for the corporations to take steps towards CSR [17].

As the UN GC is a voluntary initiative, the board plays a fundamental role in this decision-making and affiliation, and more importantly, finding the right combination and amount of diversity for boards is crucial for organizational effectiveness [18]. That the right combination and the greater presence of women on the board respond to a higher commitment to social issues and responsiveness was reported by references $[19,20]$, among others. This also represents a superior commitment to CSR initiatives such as the voluntary climate change disclosure for the Carbon Disclosure Project (CDP) [21,22] and the high-quality disclosure of CSR information following the Global Reporting Initiative (GRI) guidelines [23]. Board gender diversity (BGD) effectiveness could also be emphasized by the existence of a CSR committee as it plays a crucial role in the prioritization of CSR-related issues [24] and acts as an instrument that tends to improve responsible management and social performance [25].

The above are only some examples of previous studies focused on BGD and the existence of CSR committees on the board and how they are committed to promoting and implementing CSR initiatives, ignoring in any case, the firm's adoption of the UN GC. This paper proposes the following question due to the lack of prior evidence in this regard: how do female directors on the board behave towards the firm's affiliation with the UN GC as a CSR initiative? How can the existence of a CSR committee mediate the above relationship?

In resolving the lack of evidence about the board determinants of adoption of the UN GC, the aim of this study was to investigate whether BGD and the presence of a CSR committee have an impact on the adoption of the UN GC. To test the above research gap, an examination was made of 29,951 firm-year observations from 2012-2018 from 64 different countries representing the North and South American, European, African, and Asian Pacific stock markets. The findings revealed that female directors on the board as a means of BGD significantly encouraged the firm's affiliation with the UN GC both directly and indirectly (via the presence of a CSR committee). The positive impact of female directors on the UN GC signatory appears to be mediated by the existence of a CSR committee. Therefore, the results support the positive effect of BGD and the mediating role exerted by a CSR committee on the relationship with BGD-UN GC adoption.

By highlighting the positive effect of BGD and the mediating effect of the existence of a CSR committee on the firm's affiliation with the UN GC, this research contributes to prior literature in several aspects. This study reinforces the understanding of the UN GC initiative from a board perspective by identifying and addressing the research gap of the lack of study of the influence of board structure and composition on the firm's affiliation with the UN GC. This issue remains largely unexplored in the current literature and even more distinctly, from an international perspective. To date, the studies on the analysis of the determinants of UN GC signatories were limited and the few studies conducted on the topic only investigated external $[13,14]$ and internal pressures $[15,16]$. However, these studies neglected board influence on this signatory despite the fact that this influence is an internal factor that exerts a clear pressure on the firm's commitment to sustainability issues. The study is one of the first studies that aimed to empirically demonstrate the positive impact of BGD on a UN GC signatory, mediated by the existence of a CSR committee, to provide evidence of a board's influence on a UN GC signatory. The authors believe that the present paper could contribute to the literature by demonstrating how female directors and CSR committees influenced UN GC signatories, in other words, how internal corporate factors influenced affiliations with the UN GC. Furthermore, although there are several studies on other types of committees, such as auditory, environmental, health, safety, etc., established by boards, only a limited number of research papers on CSR committees were identified. Furthermore, the majority of these studies focused on the consequences of the presence of a CSR committee in firms [26-31]. Only a few [32,33] investigated the antecedents of the presence of a CSR committee. Thus, the present study could also contribute to the literature by testing whether BGD was an antecedent of the presence of a CSR committee in firms. 
In this regard, although some previous studies have investigated the effects of BGD $[21-23,34]$ and the presence of a CSR committee [26-31] on various CSR initiatives, such as GRI and CDP, as far as the authors know, there is no study in the literature that has specifically examined the effects of BGD and CSR committee on the adoption of the UN GC. It is true that the previous evidence in terms of CSR issues can be assimilated to the UN GC signatory; however, CSR issues are perceived from a micro-perspective, while initiatives such as UN GC or sustainable development goals cast a macro-perspective by focusing on changes at the global level and not at the company level. The influence of BGD and the mediating effect of the CSR committee should be examined in order to check whether the effect of BGD and CSR committees on CSR performance and reporting remains when UN GC signatory status is examined. Finally, it should also be emphasized that the sample is composed of international firms in 64 countries, whereas previous studies have focused on single country analysis (e.g., reference [11] examined the Spanish context; [35] analyzed French firms; [31] UK firms; [26] focused on Pakistan; and [36] examined Turkish companies). Therefore, this study provides interesting results and implications for international firms.

This study is broken down into four sections. The following Section 2 presents the theoretical background about the topic and the research hypotheses. Section 3 focuses on research design (sample, models of analysis, variables, etc.). Section 4 discusses the research results, followed by Sections 5 and 6 where the main results are discussed and concluding remarks, implications, and limitations are presented, respectively.

\section{Theoretical Background and Research Hypotheses about the Firm's Affiliation with the UN Global Compact}

\subsection{UN Global Compact}

Although known to be different from each other in detail [11], there are several well-known CSR initiatives that are mandatory or voluntary at the industry, country, or global levels [37]. Examples of the above are the AA 1000, AccounAbility, Caux Roundtable Principles for Business, CERES Principles, Equator Principles, Fair Labor Association Workplace Code, Global Reporting Initiative (GRI), Global Sullivan Principles, ISO 14000, ISO 26000, OECD Guidelines for Multinational Enterprises, Principles for Responsible Management Education, Social Accountability (SA) 8000, The Clarkson Principles of Stakeholder Management, The Ethical Trading Initiative, The Fair Labor Association, The Marine Stewardship Council, Tripartite Declaration of Principles Concerning Multinational Enterprises, and so on $[4,6,9,11,13,38]$.

As a principle-based CSR initiative [4], United Nations Global Compact (UN GC) "is a voluntary initiative promoting responsible global corporate citizenship" [39] (p. 37). As emphasized above, the UN GC includes 10 principles within four main pillars of "human rights" (principles 1 and 2), "labor" (principles 3, 4, 5, and 6), "environment" (principles 7, 8, and 9), and "anti-corruption" (principle 10) [40]. The pillar of "anti-corruption" with the single principle was added in 2004 [7,14] whereas the other three pillars have existed since its inception. These principles of the UN GC were largely inspired by the "Declaration of Human Rights" (1948), "Rio Declaration on Environment and Development" (1992), "Fundamental Principles of Rights at Work" of the International Labour Organisation (1998), and the "UN Convention Against Corruption" (2003), respectively [2,6,8,11,14,41].

GC is also a local and global network comprising various groups of actors fulfilling manifold functions in the initiative, such as companies (business organizations with 250 or more employees), SMEs, business associations, labor organizations, non-governmental organizations, academic organizations, foundations, city administrations, governments, think-tank organizations, and CSR organizations [4,5,42]. Therefore, it is a good example of "complex multilateralism at global level" [43] (p. 1). It also serves as a discussion and co-learning platform for participants of this network $[8,44]$ where members exchange their experiences about CSR with each other. The leaders of candidate organizations for membership, for example the CEO of a company, should send a signed letter to the Secretary-General of the UN to underline commitments of their organizations to the UN GC and 
its principles. However, membership of actors can be terminated when actors continuously fail to communicate their progress to the UN GC within the time limits $[5,44]$ in an annual report, namely "Communication on Progress (CoP)". Indeed, information about 13,018 de-listed participants [45] has been shared with those concerned on the website of the UN GC. Finally, it should be emphasized that the decision for de-listing is made when the related member has failed to report progress in a timely manner as stated above. The decision is not based on the veracity and/or quality of information shared in the reports by members [46].

When CSR initiatives are compared with each other in terms of the number of members, the UN GC is the largest [1,7,47] possibly due to its "rapid grow to scale strategy" [8] (p. 4), its characteristic of "an extremely low barrier to entry" [13] (p. 230), and its documented benefits to members. It is possibly the most well-known of the CSR initiatives [38]. Indeed, the UN GC, which was announced in January 1999 as an idea by Secretary-General Kofi Annan at the World Economic Forum in Switzerland and was formally established in 2000, has 14,140 members in 166 countries worldwide, as of 9 April, 2020. Of these members, 10,715 (about 76\%) are SMEs and companies [45]. When the geographical distribution of the members is examined, the dominance of members from European countries can be observed easily [9]. The largest contributor to the UN GC is Spain with 1591 (about $11 \%$ of all members) member organizations [45]. In contrast, the UN GC has experienced some difficulties in attracting American, Canadian, and Australian organizations [1,13,42]. To emphasize this point, the differences between countries based on the number of participant actors were investigated [14], and it was reported that the level of national participation in the UN GC was affected by the level of democracy and participation by countervailing groups (e.g., labor unions, citizen groups) in that country. In a similar vein, it was found that corporations in countries with strong labor rights, a collectivist culture, and longer stock trading history were more prone to join the UN GC [48].

Behind this popularity of the initiative, there may be some positive outcomes of joining the UN GC for members, which have been discussed and reported by several studies. For example, recent studies that integrated ethical and economic perspectives to CSR revealed that becoming a member of the UN GC had positive impacts on competitive advantage and market performance of firms [1]. In addition, many studies $[4,5,7]$ have emphasized the legitimizing effect of joining the UN GC for business organizations due to the existence of an international actor, the UN. In addition, some crucial actors from the investment community previously announced that they would take socially responsible behavior of companies into consideration when making investment decisions [42]. Consistent with this, a Multinational Company (MNC) joining the UN GC created a positive impact on investors except in the context of US-based MNCs [2]. In a similar vein, Kimbro and Cao [3], in their studies where they asked the question of "does voluntary corporate citizenship pay?", also found significant differences between communicating and non-communicating member firms of the UN GC in terms of some criteria such as investment opportunity, returns on assets, and equity. Finally, a study by Orzes et al. [6] revealed that UN GC member firms perform significantly better than non-members in sales growth and profitability. In addition, variables of country development and cultural features were seen to moderate the relationship between UN GC membership and sales performance. The study also showed that the relationship between UN certification and profitability was also moderated by $\mathrm{UN}$ vendorship.

In spite of these reported positive outcomes of the UN GC, it is not completely free of criticism. For example, some NGOs express concerns that firms will draw upon the legitimacy of the UN without making significant progress in unfair business practices [4], namely "blue washing" [9,38] or "ceremonial adoption" [49], in the language of institutional theory. Berliner and Prakash [50] indicated that members of the UN GC showed worse performance on issues of environment and human rights which entail high costs. These firms enjoy the reputational impact of becoming a member of the UN GC by only focusing on peripheral low-cost issues of environment and human rights. In contrast, Kell et al. [42] claimed that the UN GC does not create an opportunity for blue washing, and failed members that cannot make progress can be even more vulnerable to opposition. Another criticism is 
that there is an unbalanced representation of different actors in this platform. For example, Fritsch [43] showed that NGOs and labor organizations are under-represented in the UN GC compared to business organizations. In addition, in respect of business organizations, some people see the initiative as the first step on the path to global regulation that will slow down economic growth. Another criticism of the UN GC is that it does not suggest a framework for reporting and does not evaluate and confirm the submitted reports. At this point, some actors can fill this gap with individual efforts. For example, Amer [5] reported that socially responsible investors can increase the effectiveness of the UN GC by taking an active role in the monitoring of companies. Finally, some criticisms have drawn attention to the danger that the agenda of the UN can be occupied by business organizations [4] through the UN GC.

Moreover, it should be emphasized that the decision of companies to adopt the UN GC should not be conceived as unlimited freedom. For example, the adoption of the UN GC by large organizations can create some strong institutional pressures on others to mimic spearhead organizations and to adopt this practice $[4,11]$. It is also a multi-stakeholder CSR initiative that encourages corporations to find some cures for problems [1] on issues collected under the four main areas and 10 principles. At this point, it should be emphasized that the alignment of strategies, cultures, and operations of organizations to these universally accepted principles is expected by the initiative $[35,41,47]$.

\subsection{Board Gender Diversity as Determinant of UN Global Compact Signatory}

The growing popularity of the UN GC has been clouded during the last 20 years, because many corporate scandals have been experienced in the business world such as Enron, Volkswagen, WorldCom, etc. [51]. As a result of these scandals, corporations have largely lost trust in the eyes of stakeholders and concerns about board effectiveness have increased enormously [52]. Therefore, many countries have taken precautions to prevent a recurrence of these events by issuing new corporate governance legislation or supporting board diversity, particularly BGD. This development has triggered discussions about women on corporate boards and the impact on board performance [53]. Since the board is the ultimate decision-making position in corporations for many decisions, finding the right combination and amount of diversity for boards is crucial for organizational effectiveness [18].

It is fair to say that there is comprehensive literature about the impacts of women's representation on corporate boards on the economic outcomes of organizations. This literature anticipates that female board members will augment the financial performance of organizations by bringing their unique abilities, skills, experiences with them to boards [52]. Although there are also some studies that showed reversed or insignificant effects [54,55], some previous studies have empirically revealed that a greater presence of women on boards has some crucial and positive impacts on various points of the firm's financial performance, such as having higher return on equity and the market-to-book value of equity than firms with no women on the board [18]; lower variability in corporate performance [56]; enhanced return on assets (ROA), equity (ROE) and sales (ROS) [52]; boosted innovation [57]; and augmented the ROA and Tobin's Q [58,59].

Another reason for encouraging the participation of women on corporate boards is the belief that they are much more sensitive than men about social issues [60]. Thus, female directors will enhance the social performance of corporations under the premise that they often behave consistently with gender stereotypes [61] with women being more empathetic and helpful than men, and showing a greater commitment to CSR initiatives. When the characteristics of female board members are examined, it is seen that females are often placed as independent members of boards. It has also been observed that women are often more likely to have a participatory leadership style than men, which facilitates discussion and focus on social issues [53]. Therefore, it may be expected that an increase in the ratio of female board members will result in higher corporate social performance.

Although the empirical literature presents heterogenous findings on this point [62], consistent with the above premise, the majority of studies have found a relationship between the percentage of women on the board and a higher commitment to social issues [20]. For example, the results of 
Williams's research [63] indicated that a higher percentage of women on boards has a significant effect on both the overall charitable giving level of the firm and particularly levels of charitable giving to "community service organizations" and "arts and cultural programs". Similarly, Bernardi et al. [61] indicated an association between the representation of women on the board and being on the list of the "Most Ethical Companies". Consistent with previous studies, Galbreath [18] found a positive relationship between BGD and social responsiveness, which was regarded as one of three pillars of sustainability in that study. Finally, a study by Zhang [19] based on publicly traded Fortune 500 companies also indicated a significant effect of BGD on corporate social performance.

In addition to the impact of BGD on overall corporate social behavior, a relatively limited number of studies have examined the more specific point of the relationship between BGD and issues related to CSR initiatives. For example, two studies [21,22] revealed that BGD is positively and significantly linked to the likelihood of voluntary climate change disclosure for the Carbon Disclosure Project, a CSR related initiative [64]. Issa and Fang [23] conducted research in six Arab Gulf States and found a relationship between BGD and the level of CSR reporting in the context of GRI. In a similar vein, a study by Valls Martinez et al. [20] indicated a positive and significant effect of BGD on GRI disclosure, and more recently, Haque and Jones [34] found a relationship between BGD and disclosure of biodiversity initiatives (DBIs).

In conclusion, although some studies have not found any significant relationship between BGD and affiliation with some CSR initiatives [65], a positive outcome on CSR initiatives of BGD is expected from initiatives in papers focusing on UN GC signatories. Therefore, based on prior arguments, the following hypothesis is proposed under the expectation that a greater presence of female directors on the board encourages firms to affiliate to the UN GC:

Hypothesis 1 (H1). The greater the board gender diversity, the higher probability of affiliation of a firm with the UN Global Compact.

\subsection{The CSR Committee as Mediator}

Since the board of directors influences the decision-making processes of organizations, corporate governance gives crucial tasks to boards and holds them responsible for performance and all activities of the organization [66]. As a result of this understanding that holds the board responsible to all stakeholders, the board of directors also emerges as a system [36]. These systems bring committees in boards into question for aims such as providing broader participation and conducting more transparent management. These committees have crucial functions, operating on various issues and advising the board [67]. Committees of the board have a strategic role in some areas such as organizational legitimacy, accountability, transparency, and diffusion of best practices, and are important to increase the effectiveness of corporate governance in the context of conflicting interests. In many organizations all around the world, audit committees, risk committees, and shareholder committees are widely seen $[26,33]$. In addition to these committees, some others that are temporary or permanent can be seen in practice.

The idea of "beyond only producing product and services, organizations should make contributions to societies that improve their quality of life", which first came to the agenda of the Committee for Economic Development (CED) in 1971 [68], has caused some crucial developments over the subsequent years. Particularly, due to increased use of communication tools, an awareness of social responsibility at the societal level has emerged and the tendency of stakeholders to monitor the CSR activities of organizations has increased day by day [69]. In addition to this, with the emergence of some global agreements/initiatives such as UN GC, GRI, ISO 26000, OECD Principles of Corporate Governance, etc., the formulation and implementation of strategies on environmental, social, and governance (ESG) issues, and sharing the results of implementation have become almost compulsory for organizations [24]. Therefore, organizations often develop some instruments at the level of the board of directors to manage 
their social and environmental operations and to institutionalize these responsible behaviors due to the above-mentioned changes in the expectations of societies [70]. As an example of these mechanisms, while some corporations establish CSR committees [26], others form other types of committees on special issues such as ethics, sustainability, environment, health, and safety [33].

In recent years, many corporations have established CSR committees which are held responsible for the formulation and implementation of CSR strategies and sustainability policies of the related organization [71]. A CSR committee in a board plays a crucial role in the prioritization of CSR-related problems, the generation of solutions for these problems, and making reports to the board of directors [24]. The existence of a CSR committee can be regarded as evidence of the importance given to the responsibilities to stakeholders. It can also be accepted as a mechanism that investigates, controls, and prevents irresponsible activities. In addition to these outcomes, a CSR committee often has the authority to audit all CSR activities and compliance with CSR and ethical standards of the corporation [67]. Therefore, a CSR committee is an instrument that tends to improve responsible management and social performance [25]. Thus, can the existence of a CSR committee influence the firm's affiliation to the UN GC or the effect of BGD on this adoption?

To answer the preceding questions, it should be highlighted that the existence of CSR committees seems to be related to BGD and affiliation with the UN GC, that is, antecedent and consequence of the existence of CSR committees, respectively. Since CSR committees are very recent governance structures [72,73], there is a very limited number of studies in the literature that have investigated the antecedents of the presence of a CSR committee in organizations. One of these studies by Gennari [32] revealed that soft laws (national self-disciplined codes) and industry risk (only partially supported) have significant and positive impacts on the presence of a CSR committee. Gennari and Salvioni [33] found that mandatory non-financial disclosure had a significant impact on the existence of a CSR committee. However, independent variables such as the presence of soft law, high level of perceived corruption in that country, informal constraints, etc. have not been found to have a significant impact.

Focusing on how a CSR committee can mediate on the relationship between BGD and becoming a UN GC signatory has led to the evaluation that some studies in the literature show a significant and positive relationship between the existence of a CSR committee and CSR performance and affiliation with some CSR-based initiatives. For example, Helfaya and Moussa [31] and Ashfaq and Rui [26] found a relationship between the existence of a CSR committee and practices related to corporate social and environmental disclosure (CESD) in the contexts of UK and Pakistan, respectively. In a similar vein, Baraibar-Diez and Odriozola [27], Cucari et al. [28], and Brindelli et al. [74] revealed that firms with a CSR committee have significantly higher ESG scores or disclosures than firms with no committee. A study based on firms in the Dow Jones Sustainability Indices revealed that $40 \%$ of firms have a CSR committee and the existence of these committees increases social performance [71]. In a similar manner, García-Sánchez et al. [30] found that the presence of a CSR committee had direct and indirect (via introduction of an external assurance service) effects on the adoption of a combination of GRI and IFC performance standards. In another empirical study, it was indicated that it is less likely for firms with a CSR committee to perform corporate social irresponsibility (CSiR)" [67]. Finally, Kilic and Kuzey [36] showed in the context of Turkish firms that the possibility of firms being responsive will increase when they have a sustainability committee. CSR committees as a sub-committee of the board wield a crucial amount of power about CSR-related issues [24].

The above arguments support the premise that the existence of a CSR committee can be thought of as a trigger for acceptance of the UN GC, which is seen as a voluntary and global initiative aiming to implement CSR effectively [47]. Thus, the CSR committee can impact on the relationship between BGD and the UN GC by influencing, at least in part, how female directors behave on the affiliation with the UN GC. From the above, the following hypothesis is proposed:

Hypothesis 2 (H2). The existence of a CSR committee mediates the relationship between board gender diversity and the firm's affiliation with the UN Global Compact. 


\section{Data and Method}

\subsection{Sample}

The initial sample comprised 9985 firms, gathered from Thomson Reuters Eikon, for the fiscal period 2012-2018. The paper limited the sample to the universe of publicly held companies in North America, Latin America, Europe, Africa, and Asia Pacific, which appeared on 31 stock indices. The authors removed observations with missing variable data, resulting in 79,880 firm-year observations. Once duplicates were removed, as well as observations with missing information about the UN GC, the study included a balanced panel of data of 29,951 firms for eight years. The firms were located in 64 different countries.

\subsection{Model and Technique of Analysis}

This paper examines the effect of gender diversity $(\mathrm{H} 1)$ and the mediating effect of the existence of a CSR committee (H2). The analysis of the research hypotheses was examined by estimating a set of models about the effect of BGD on the UN GC signatory and the mediating effect of the existence of a CSR committee. To test these mediating effects, the authors followed the Baron and Kenny [75] process in three steps. First, the mediator (the existence of a CSR committee) was regressed on the independent variable (BGD). Second, the dependent variable (the UN GC signatory) was regressed on the independent variable. Third, the dependent variable was regressed on both the independent and mediator variables. At this stage, Baron and Kenny [75] (p. 1177) required that "the effect of the independent variable on the dependent variable must be less in the third step than in the second step".

Thus, the set that includes models 1 to 3 allowed the mediating analysis of the presence of a CSR committee, while model 2 allowed the investigation of the effect of BGD on the UN GC signatory. In model 1 , the presence of a CSR committee (the mediator) was the dependent variable and was regressed on the BGD indicator (the independent) and certain control variables. In model 2, the UN GC (the dependent variable) was regressed on the BGD indicator and certain control variables that allowed to test H1. Finally, in model 3, the same dependent variable (the UN GC indicator) was again regressed on BGD indicator but also on the presence of a CSR committee (the mediator) and certain control variables.

The three models are as follows:

$$
\begin{aligned}
& \operatorname{Prob}(\text { CSRCom })_{\text {it }}=\beta_{1} \text { FBD }_{\text {it }}+\beta_{2} \text { Size }_{i t}+\beta_{3} \text { Leverage }_{i t}+\beta_{4} \text { Beta }_{i t}+\beta_{5} \text { ROA }_{i t} \\
& +\beta_{6} \text { R\&D }_{i t}+\beta_{7} \text { Growth }_{i t}+\beta_{8} \text { BoardSize }_{i t}+\beta_{9} \text { BoardInd }_{i t} \\
& +\beta_{10} \text { Year }_{t}+\beta_{11} \text { Industry }_{t}+\beta_{12} \text { Country }_{i}+\eta_{i}+\mu_{i t} \\
& \operatorname{Prob}(\text { UNGC })_{\text {it }}=\alpha_{1} \text { FBD }_{\text {it }}+\alpha_{2} \text { Size }_{i t}+\alpha_{3} \text { Leverage }_{i t}+\alpha_{4} \text { Beta }_{i t}+\alpha_{5} \text { ROA }_{i t} \\
& +\alpha_{6} \text { R\&D }_{\text {it }}+\alpha_{7} \text { Growth }_{i t}+\alpha_{8} \text { BoardSize }_{i t}+\alpha_{9} \text { BoardInd }_{i t} \\
& +\alpha_{10} \text { Year }_{\mathrm{t}}+\alpha_{11} \text { Industry }_{\mathrm{t}}+\alpha_{12} \text { Country }_{\mathrm{i}}+\eta_{\mathrm{i}}+\mu_{\mathrm{it}} \\
& \operatorname{Prob}(\text { UNGC })_{\text {it }}=\delta_{1} \text { FBD }_{\text {it }}+\delta_{2} \text { CSRCom }_{i t}+\delta_{3} \text { Size }_{i t}+\delta_{4} \text { Leverage }_{i t}+\delta_{5} \text { Beta }_{i t}
\end{aligned}
$$

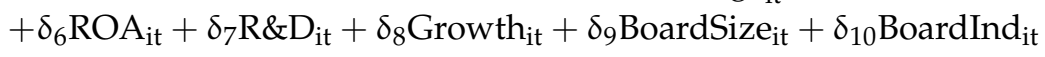

$$
\begin{aligned}
& +\delta_{11} \text { Year }_{\mathrm{t}}+\delta_{12} \text { Industry }_{\mathrm{t}}+\delta_{13} \text { Country }_{\mathrm{i}}+\eta_{\mathrm{i}}+\mu_{\mathrm{it}}
\end{aligned}
$$

where

UNGC represents the UN GC signatory as a dummy variable code as 1 if firms were affiliated with the UN Global Compact for the year covered by the financial statements, and 0 otherwise $[15,35,76]$;

BGD represents board gender diversity as the percentage of female directors on the board [77,78];

CSRCom represents the existence of a CSR committee as a dummy variable code as 1 if the firm had a CSR committee, and 0 otherwise [29,30,79];

Size represents firm size as the natural logarithm of total assets $[11,15,76,80]$;

Leverage represents firm leverage as the ratio of total debt to total equity $[35,76,80]$; 
Beta represents the systematic risk in each year [35];

ROA represents firm profitability as the return on assets ratio [80];

$R \& D$ (Research \& Development) represents the R\&D intensity as the ratio of total expenses in $R \& D$ to total assets [76,80];

Growth represents the firm's growth as the ratio of total assets in year $t$ to total assets in year $\mathrm{t}-1$ [35];

BoardSize represents board size as the total number of directors on board [30,81];

BoardInd represents board independence as the percentage of independent directors over the total directors on the board $[30,79,81]$;

$\beta, \alpha$ and $\delta$ represent the estimating parameters;

$\eta$ i represents the unobservable heterogeneity;

$\mu$ it represents the classical error term;

i represents the firm;

$\mathrm{j}$ represents the year.

This paper also controlled industry, country, and year using dummy variables representing each industry, country, and year analyzed.

The above-mentioned models were examined using dependence techniques for panel data. The use of a panel data set enhanced the consistency and explanatory power of the regression analysis at a time that provided more informative data and greater variability. It also allowed control of unobservable heterogeneity. As a technique of analysis, the authors had to consider where both dependent variables were dummy variables-“UNGC" and "CSRCom"- then, the technique of analysis had to be adequate for variables taking 0 and 1 . Logit regression was proposed as a binary probability model widely adopted in business research [82].

\section{Results}

\subsection{Univariate Results}

The sample distribution by country is summarized in Table 1 . The countries over-represented in the sample were the USA (31.5\%), followed by Japan $(9.6 \%)$, the UK $(5.93 \%)$, Canada $(5.38 \%)$, and Australia (5.12\%). The frequency of firms that sign the UN GC appeared to be greater in Cyprus and Papua New Guinea with $100 \%$ frequency from their observations. There was noticeably greater participation of firms in countries such as Portugal (78.72\%), Denmark (almost 70\% of frequency), France $(63.97 \%)$, and Spain $(63.06 \%)$. This paper also highlights the low level of participation of USA firms $(6.53 \%)$ and UK firms $(17.92 \%)$, as those countries were over-represented in the sample. Moreover, the study provided the results for the UN GC signatory of the Kruskal-Wallis H test for examining the existence of significant differences between two or more groups. Examining the Kruskal-Wallis test by country, the authors observed that the significance level is 0.001 for country. Thus, there was a significant difference in the likelihood of being a signatory of the UN GC considering the country where firms are located.

Table 1. Univariate analysis. UN Global Compact (GC) signatory by country. Kruskal-Wallis test of differences.

\begin{tabular}{ccc}
\hline & UN Global Compact Signatory & \\
\hline Panel A: Distribution & Freq. & $\%$ \\
\hline Non-UNGC & 24,405 & 81.48 \\
UNGC & 5446 & 18.52 \\
Total & 29,951 & 100.00 \\
\hline
\end{tabular}


Table 1. Cont.

\begin{tabular}{|c|c|c|c|}
\hline Panel B: Industry & Obs. & Non-UNGC (\%) & UNGC (\%) \\
\hline Argentina & 37 & 97.30 & 2.70 \\
\hline Australia & 1534 & 92.18 & 7.82 \\
\hline Austria & 112 & 60.71 & 39.29 \\
\hline Belgium & 182 & 74.18 & 25.82 \\
\hline Bermuda & 149 & 94.63 & 5.37 \\
\hline Brazil & 578 & 57.44 & 42.56 \\
\hline Canada & 1610 & 91.37 & 8.63 \\
\hline Cayman Islands & 15 & 100 & 0 \\
\hline Chile & 181 & 88.95 & 11.05 \\
\hline China & 949 & 90.62 & 9.38 \\
\hline Cyprus & 7 & 0 & 100 \\
\hline Czech Republic & 31 & 100 & 0 \\
\hline Denmark & 193 & 30.57 & 69.43 \\
\hline Egypt & 64 & 78.13 & 21.88 \\
\hline Faroe Islands & 1 & 100 & 0 \\
\hline Finland & 244 & 43.44 & 56.56 \\
\hline France & 630 & 36.03 & 63.97 \\
\hline Germany & 612 & 54.90 & 45.10 \\
\hline Gibraltar & 3 & 100 & 0 \\
\hline Greece & 106 & 59.43 & 40.57 \\
\hline Guernsey & 10 & 100 & 0 \\
\hline Hong Kong & 727 & 967.52 & 2.48 \\
\hline Hungary & 29 & 51.72 & 48.28 \\
\hline India & 725 & 69.66 & 30.34 \\
\hline Indonesia & 304 & 91.78 & 8.22 \\
\hline Ireland; Republic of & 187 & 87.17 & 12.83 \\
\hline Isle of Man & 9 & 100 & 0 \\
\hline Israel & 19 & 100 & 0 \\
\hline Italy & 315 & 64.13 & 35.87 \\
\hline Japan & 2874 & 73.38 & 26.62 \\
\hline Jersey & 29 & 79.31 & 20.69 \\
\hline Korea; Republic (S. Korea) & 849 & 66.20 & 33.80 \\
\hline Luxembourg & 70 & 71.43 & 28.57 \\
\hline Macau & 21 & 100 & 0 \\
\hline Malaysia & 336 & 94.35 & 5.65 \\
\hline Malta & 23 & 100 & 0 \\
\hline Mexico & 227 & 67.84 & 32.16 \\
\hline Monaco & 9 & 100 & 0 \\
\hline Morocco & 15 & 73.33 & 26.67 \\
\hline Netherlands & 274 & 63.87 & 36.13 \\
\hline New Zealand & 209 & 95.69 & 4.31 \\
\hline Norway & 158 & 43.04 & 56.96 \\
\hline Pakistan & 17 & 100 & 0 \\
\hline Panama & 7 & 100 & 0 \\
\hline Papua New Guinea & 7 & 0 & 100 \\
\hline Philippines & 165 & 94.55 & 5.45 \\
\hline Poland & 187 & 74.33 & 25.67 \\
\hline Portugal & 47 & 21.28 & 78.72 \\
\hline Puerto Rico & 16 & 100 & 0 \\
\hline Russia & 7 & 100 & 0 \\
\hline Singapore & 302 & 83.11 & 16.89 \\
\hline South Africa & 599 & 80.47 & 19.53 \\
\hline Spain & 314 & 36.94 & 63.06 \\
\hline Sweden & 574 & 40.07 & 59.93 \\
\hline Switzerland & 540 & 66.30 & 33.70 \\
\hline Taiwan & 828 & 100 & 0 \\
\hline Thailand & 249 & 73.49 & 26.51 \\
\hline Turkey & 205 & 81.46 & 18.54 \\
\hline
\end{tabular}


Table 1. Cont.

\begin{tabular}{cccc}
\hline Panel B: Industry & Obs. & Non-UNGC (\%) & UNGC (\%) \\
\hline Ukraine & 7 & 100 & 0 \\
United Kingdom & 1775 & 82.08 & 17.92 \\
United States of America & 9436 & 93.47 & 6.53 \\
Vietnam & 7 & 100 & 0 \\
Virgin Islands; British & 2 & 100 & 0 \\
Virgin Islands; United States & 3 & 100 & 0 \\
\hline
\end{tabular}

Kruskal-Wallis test; Chi-squared with ties $=5667.77$ with 63 d.f.; Probability $=0.0001 ; \mathrm{N}=29,951$ firm-year observations.

Table 2 reports the main descriptive analysis for the variables used in the regression models, except for industry, country, and year dummies, breaking down the analysis in two sub-samples according to the non-signatory of the UN GC and the signatory of it. The main descriptive evidence reported the frequency of affiliation of firms in the sample analyzed to be $18.52 \%$. As Abdelzaher et al. [48] reported, the level of participation among publicly-traded corporations remained low. Regarding the female representation on boards, on average the board of a firm had around 16 female directors, a percentage that increased towards almost $20 \%$ for firms that signed the UN GC. Similarly, approximately $50 \%$ of the firms examined had a CSR committee, a percentage that also increased to an impressive $85.24 \%$ for firms affiliated with the UN GC. The above descriptive results showed initial evidence of the possible effect of board diversity and a CSR committee on a firm's affiliation with the UN GC. The remaining descriptive statistics for control variables and correlation coefficients are in Tables 2 and 3, respectively. In general, the bivariate correlations among variables were not high; thus, there could be no multicollinearity problems in the proposed regression models.

Table 2. Descriptive statistics.

\begin{tabular}{ccccccc}
\hline & \multicolumn{2}{c}{ Full Sample } & \multicolumn{2}{c}{ Non-UNGC } & \multicolumn{2}{c}{ UNGC } \\
\hline & Mean & Std. Dev. & Mean & Std. Dev. & Mean & Std. Dev. \\
\hline BGD & 15.511 & 12.752 & 14.625 & 12.257 & 19.482 & 14.103 \\
Size & 22.451 & 1.790 & 22.225 & 1.710 & 23.443 & 1.795 \\
Leverage & 1.043 & 16.191 & 1.016 & 17.672 & 1.162 & 6.451 \\
Beta & 1.013 & 0.564 & 1.008 & 0.567 & 1.038 & 0.552 \\
ROA & 0.041 & 0.128 & 0.041 & 0.135 & 0.041 & 0.089 \\
R\&D & 0.068 & 1.297 & 0.078 & 1.475 & 0.034 & 0.062 \\
Growth & 62.268 & 8927.761 & 74.372 & 9891.084 & 9.063 & 125.104 \\
BoardSize & 10.144 & 3.391 & 9.773 & 3.187 & 11.771 & 3.760 \\
BoardInd & 45.050 & 24.166 & 43.478 & 23.894 & 49.529 & 24.377 \\
\hline & Freq. & $\%$ & Freq. & $\%$ & Freq. & $\%$ \\
\hline UNGC & 5546 & 18.52 & - & - & - & - \\
CSRCom & 14,683 & 50.85 & 10,088 & 43.01 & 4,555 & 85.24 \\
\hline
\end{tabular}

Sample: 29,951 firm-year observations from 2012 to 2018.

Table 3. Correlation matrixes.

\begin{tabular}{|c|c|c|c|c|c|c|c|c|c|c|c|}
\hline & 1 & 2 & 3 & 4 & 5 & 6 & 7 & 8 & 9 & 10 & 11 \\
\hline 1. UNGC & 1.000 & & & & & & & & & & \\
\hline 2. BGD & $0.147^{* * *}$ & 1.000 & & & & & & & & & \\
\hline 3. CSRCom & $0.328^{* * *}$ & $0.130^{* * *}$ & 1.000 & & & & & & & & \\
\hline 4. Size & $0.264 * * *$ & $0.082 * * *$ & $0.311^{* * *}$ & 1.000 & & & & & & & \\
\hline 5. Leverage & 0.004 & 0.009 & 0.008 & $0.027^{* * * *}$ & 1.000 & & & & & & \\
\hline 6. Beta & $0.021^{* * *}$ & $-0.027^{* * *}$ & 0.006 & $0.039^{* * *}$ & $0.018^{* *}$ & 1.000 & & & & & \\
\hline 7. $\mathrm{ROA}$ & 0.000 & $0.050^{* * *}$ & $0.042 * * *$ & $0.016^{* * *}$ & -0.013 ** & $-0.024^{* * *}$ & 1.000 & & & & \\
\hline 8. $\mathrm{R} \& \mathrm{D}$ & -0.014 & $0.028 * * *$ & $-0.208^{* * *}$ & $-0.107^{* * *}$ & -0.002 & $-0.038 * *$ & $-0.034 * * *$ & 1.000 & & & \\
\hline 9. Growth & -0.003 & -0.00 & 0.006 & 0.005 & 0.001 & 0.006 & -0.002 & -0.001 & 1.000 & & \\
\hline 10. BoardSize & $0.229 * * *$ & $0.065^{* * *}$ & $0.240^{* * *}$ & $0.467^{* * *}$ & $0.017^{* * *}$ & -0.008 & $-0.013 * *$ & $-0.138^{* * *}$ & -0.001 & 1.000 & \\
\hline 11. BoardInd & $0.110^{* * *}$ & $0.416^{* * *}$ & $0.124^{* * *}$ & $-0.031^{* * *}$ & 0.009 & 0.005 & $0.021^{* * *}$ & $0.085^{* * *}$ & 0.008 & -0.187 & 1.000 \\
\hline
\end{tabular}

Sample: 29,951 firm-year observations from 2012 to 2018 . Significance levels: ${ }^{*} p<0.10$; ${ }^{* *} p<0.05$; ${ }^{* * *} p<0.01$. 
4.2. Regression Results: The Impact of Board Gender Diversity on the UN Global Compact Signatory and the Mediating Effect of a CSR Committee

The main results of this study are those reported in Table 4, which examine the firm's affiliation with the UN GC, the effect of BGD, and the mediation effect of a CSR committee. The results of model 1 clearly confirmed the positive and significant relationship between the presence of female directors on the board and the existence of a CSR committee $\left(\beta_{1}=0.119, p<0.01\right)$. Therefore, the greater the BGD, the greater likelihood that firms had a CSR committee specialized in social and environmental issues. Regarding the BGD as a factor influencing the likelihood of being a UN GC signatory, the results of model 2 reported the positive and significant effect of the presence of female directors on the firm's affiliation with the UN GC $\left(\alpha_{1}=0.147, p<0.10\right)$. The preceding results confirm hypothesis 1 ; that is, the greater the board gender diversity, the higher probability that the firm affiliated with the UN Global Compact.

Table 4. The mediator effect of the CSR committee on the impact of board gender diversity on the firm's affiliation with the UN Global Compact.

\begin{tabular}{|c|c|c|c|c|c|c|}
\hline \multirow{3}{*}{$\begin{array}{c}\text { Dependent } \\
\text { Variable }\end{array}$} & \multicolumn{2}{|c|}{ Model 1} & \multicolumn{2}{|c|}{ Model 2} & \multicolumn{2}{|c|}{ Model 3} \\
\hline & \multicolumn{2}{|c|}{ CSRCom } & \multicolumn{2}{|c|}{ UNGC } & \multicolumn{2}{|c|}{ UNGC } \\
\hline & Coef & Std. Error & Coef & Std. Error & Coef & Std. Error \\
\hline BGD & $0.119^{* * *}$ & 0.021 & $0.147^{* * *}$ & 0.027 & $0.075^{* * *}$ & 0.018 \\
\hline CSRCom & & & & & $2.861^{* * *}$ & 0.593 \\
\hline Size & -0.076 & 0.083 & $-0.327^{* * *}$ & 0.103 & $-0.446^{* * *}$ & 0.070 \\
\hline Leverage & 0.029 & 0.022 & 0.008 & 0.037 & 0.003 & 0.029 \\
\hline Beta & $-1.185^{* *}$ & 0.553 & $-1.257^{*}$ & 0.678 & $-0.982^{* *}$ & 0.466 \\
\hline ROA & 0.037 & 2.088 & 2.784 & 3.193 & -2.712 & 3.809 \\
\hline R\&D & $-17.136^{* * *}$ & 3.002 & -10.072 & 6.848 & $-19.599 * * *$ & 5.011 \\
\hline Growth & 0.088 & 0.374 & $-4.170^{* * *}$ & 0.952 & $-3.413^{* * *}$ & 0.907 \\
\hline BoardSize & $0.331^{* * *}$ & 0.098 & $0.254^{* * *}$ & 0.096 & $0.209 * *$ & 0.086 \\
\hline BoardInd & $0.022 *$ & 0.012 & $0.043^{* *}$ & 0.018 & $0.021 *$ & 0.013 \\
\hline \multicolumn{7}{|c|}{ Controlled by industry, country and year effects } \\
\hline sigma_u & 4.095 & 0.055 & 6.066 & 0.130 & 5.453 & 0.128 \\
\hline sigma_e & 7.747 & 0.212 & 20.755 & 1.351 & 15.281 & 0.977 \\
\hline rho & 0.948 & 0.003 & 0.992 & 0.001 & 0.986 & 0.002 \\
\hline
\end{tabular}

Sample: 29,951 firm-year observations from 2012 to 2018 . Significance levels: ${ }^{*} p<0.10 ;{ }^{* *} p<0.05 ;{ }^{* * *} p<0.01$.

In model 3, it should be again noted that to support the mediating effect of a CSR committee on the relationship between female directors and the UN GC, two requisites must be examined: (i) the significant coefficient of CSRCom and (ii) that the value of BGD coefficient is lower in model 3 than in model 2. The findings clearly meet the above two assumptions. First, the existence of a CSR committee showed a positive and significant effect on the likelihood of a firm's affiliation with the UN GC $\left(\delta_{2}=2.861, p<0.01\right)$. Thus, firms showed a greater commitment towards adherence with the UN GC under the internal pressures exerted by CSR committees. Second, the results again confirmed that female directors had a positive and significant influence on the likelihood of firms being UN GC signatories $\left(\delta_{1}=0.075, p<0.01\right)$, and this value was lower than its respective value in model 2 $\left(\alpha_{1}=0.147\right)$. Supporting hypothesis 2 , the greater affiliation of the firm with the UN GC as result of a greater BGD was influenced by the existence of a CSR committee, and the existence of a CSR committee mediates the relationship between board gender diversity and the firm's affiliation with the UN Global Compact.

Having evidenced the preceding findings, this paper conducted a complementary analysis by examining different samples to reinforce the results obtained previously. The objective was to examine 
the robustness of the findings by excluding US firm-year observations. The authors observed that a large number of the sample observations came from the USA (31.5\% of the firm-year observations of the sample). To avoid possible sample bias, the American observations were excluded, as reported in the following additional analysis. Thus, at this stage, the international sample consisted of 20,515 firm-year observations of 63 countries excluding the USA. The results were determined to be robust in the sample without the USA.

In this respect, the results from models 1 to 3 - Table 5 -inferred that the presence of females on the board had a positive impact on the firm's affiliation with the UN GC and that there was a mediating effect of the existence of a CSR committee. In detail, model 1 again confirmed the positive and significant effect of BGD on the existence of a CSR committee $\left(\beta_{1}=0.106, p<0.01\right)$. Model 2 also confirmed the positive and significant impact of BGD on the UN GC signatory $\left(\alpha_{1}=0.130, p<0.10\right)$, confirming the research hypothesis 1 ; the greater the BGD, the higher the probability of a firm to affiliate with the UN GC. As a main result, the findings of model 3 supported the mediating effect of a CSR committee by meeting the two requisites. First, the existence of a CSR committee had a positive and significant impact on the UN GC signatory $\left(\delta_{2}=2.875, p<0.10\right)$. Second, BGD showed a positive and statistically significant coefficient $\left(\delta_{1}=0.075, p<0.10\right)$, and the value was lower than its respective value in model $2\left(\alpha_{1}=0.130\right)$. The higher likelihood of affiliation with the UN GC as a result of greater gender diversity was mediated by the existence of a specialized committee for social and environmental issues. As was proposed in hypothesis 2, the existence of a CSR committee mediated the relationship between BGD and the firm's affiliation with the UN GC.

Table 5. Sensitive analysis by excluding USA firms. The mediator effect of the CSR committee on the impact of board gender diversity on the firm's affiliation with the UN Global Compact.

\begin{tabular}{|c|c|c|c|c|c|c|}
\hline & \multicolumn{3}{|c|}{ Model 1} & \multirow{2}{*}{$\begin{array}{c}\text { Model } 2 \\
\text { UNGC }\end{array}$} & \multicolumn{2}{|c|}{ Model 3} \\
\hline \multirow[t]{2}{*}{$\begin{array}{c}\text { Dependent } \\
\text { Variable }\end{array}$} & \multicolumn{3}{|c|}{ CSRCom } & & \multicolumn{2}{|c|}{ UNGC } \\
\hline & Coef & Std. Error & Coef & Std. Error & Coef & Std. Error \\
\hline BGD & $0.106^{* * *}$ & 0.020 & $0.130^{* * *}$ & 0.022 & $0.075^{* * *}$ & 0.018 \\
\hline CSRCom & & & & & $2.875^{* * *}$ & 0.592 \\
\hline Size & -0.087 & 0.076 & $3.924^{* * *}$ & 0.312 & $-0.446^{* * *}$ & 0.070 \\
\hline Leverage & 0.025 & 0.022 & 0.001 & 0.039 & 0.003 & 0.029 \\
\hline Beta & $-1.043^{* *}$ & 0.527 & $-0.972 *$ & 0.509 & $-0.975^{* *}$ & 0.455 \\
\hline ROA & -0.040 & 2.087 & 4.361 & 3.839 & -2.806 & 3.925 \\
\hline R\&D & $-16.995^{* * *}$ & 2.856 & $10.810^{* *}$ & 4.927 & $-19.639 * * *$ & 5.052 \\
\hline Growth & 0.055 & 0.369 & $-3.492 * * *$ & 0.972 & $-3.418^{* * *}$ & 0.910 \\
\hline BoardSize & $0.384^{* * *}$ & 0.089 & $0.209^{* *}$ & 0.085 & $0.207^{* *}$ & 0.086 \\
\hline BoardInd & $0.028^{* *}$ & 0.012 & $0.059^{* * *}$ & 0.012 & $0.022 *$ & 0.013 \\
\hline \multicolumn{7}{|c|}{ Controlled by industry, country and year effects } \\
\hline sigma_u & 4.044 & 0.054 & 4.848 & 0.123 & 5.453 & 0.128 \\
\hline sigma_e & 7.554 & 0.204 & 11.291 & 0.695 & 15.282 & 0.979 \\
\hline rho & 0.945 & 0.003 & 0.975 & 0.003 & 0.986 & 0.002 \\
\hline
\end{tabular}

Sample: 20,515 firm-year observations from 2012 to 2018 . Significance levels: ${ }^{*} p<0.10$; ${ }^{* *} p<0.05 ;{ }^{* * *} p<0.01$.

\section{Discussion}

This paper emphasized the positive CSR outcomes associated with a greater presence of female directors on the board of a firm, in addition to how the existence of specialized committees on CSR increased and mediated this effect. The results supported the existence of a mediating effect of the CSR committee on the impact of BGD on the adherence to the UN GC. In other words, the positive impact of the presence of female directors on the board on the affiliation with the UN GC appears to be explained by an additional board factor: the existence of a CSR committee. 
The preceding results confirmed hypothesis 1 ; that is, the greater the board gender diversity, the higher the probability of a firm to affiliate with the UN Global Compact. Overall, the evidence is consistent with previous literature that showed how a greater presence of women on boards is associated with positive firm outcomes, such as performance, market value, profitability, or innovation $[18,52,56,58,59]$. However, more specifically, the results are in accordance with previous studies that demonstrated how a greater BGD is positively associated with higher social and environmental commitment and responsiveness of a firm [19,20,53,60,61]. Focusing on CSR initiatives, the results confirm the positive impact of BGD on a firm's affiliation to the UN GC, in support of the scarce previous literature $[20-23,34,64]$ which has reported the positive impact on women on boards on voluntary non-financial (e.g., CSR) reporting.

The main finding also confirms that the existence of a CSR committee mediated the relationship between board gender diversity and the firm's affiliation with the UN GC. These results therefore confirm hypothesis 2; that is, the existence of a CSR committee on the board mediated the positive impact of BGD on the firm's affiliation with the UN GC. Beyond contributing to the limited prior literature about CSR committees, the results also support some previous studies which have reported how CSR committees are responsible for the formulation and implementation of CSR performance and reporting strategies, ethical standards, and sustainability policies [24,25,67,71].

Thus, the findings on the direct and mediating effects of a CSR committee on the firm's affiliation with the UN GC reinforces the previous evidence that demonstrated the positive influence of this committee on the promotion, adoption, and implementation of CSR-based initiatives such as becoming a UN GC signatory $[24,26-28,30,31,71,74]$.

\section{Conclusions}

The aim of this study was to examine whether board composition and structure impacted a firm's affiliation with the United Nations Global Compact. In detail, this paper examined whether board gender diversity encouraged becoming a United Nations Global Compact signatory and the mediating effect of the existence of a social responsibility committee. Thus, what board factors determined the effect of female directors on the board on the firm's affiliation with the United Nations Global Compact? To test the above research gap, this paper examined 29,951 firm-year observations from 2012 to 2018 of 64 different countries representing the North and South American, European, African, and Asian Pacific stock markets. The findings suggest that female directors on the board significantly encourage the firm's affiliation with the United Nations Global Compact and support the mediating effect of the existence of a social responsibility committee. In other words, the positive impact of female directors on the likelihood of a firm being a Global Compact signatory appears to be explained by the existence of a sustainability committee.

The results of this study have some practical implications for several agents. First of all, it should be emphasized that worldwide there is concern about social and environmental issues, which was revealed in the recent COP25 held in 2019. By 2020, the United Nations Global Compact already had 10,453 companies in 161 countries that appeared in 77,516 public reports. However, the level of participation among publicly-traded corporations is certainly low [48]. Managers should consider promoting affiliation with the United Nations Global Compact as a generally accepted standard at a global level, with the objective of aligning corporate strategies and objectives with the principles of human rights, labor, the environment, and anti-corruption [10].

In the same way and being the main decision-making body, the results of this research are especially useful to all the agents participating in the board of directors. Specifically, shareholders and investors, as well as interest groups, can find in the female directors and in the existence of a corporate social responsibility committee a mechanism that reinforces the board's commitment to voluntary socially responsibility initiatives such as the United Nations Global Compact. In this sense, the results of the study provide useful evidence for regulatory bodies to promote and further guarantee not only the existence of the social responsibility committee, but above all, the presence of female 
directors on the board. It is crucial for the firm's commitment to sustainability initiatives to have the right combination and amount of diversity on boards [18]. It is true that, over the years, minimum percentages have been established in certain countries, but the average rates of female directors on the boards are still excessively low. Regulatory bodies and national governments must work together to promote greater board diversity in terms of gender, as well as adherence to initiatives linked to socially responsible issues (human rights, environment, anti-corruption, etc.).

Nonetheless, this paper is not free of limitations. Throughout this paper, the United Nations Global Compact has been understood as the largest voluntary sustainability initiative in the world [12] and currently, the Global Compact comprises 10,715 companies as participants (April 2020). However, it should be noted that the Global Compact has also received some criticism about the difficulty of implementing its principles [83] and the final objective of a firm's affiliation with it. Thus, firms sign the United Nations Global Compact with the mere objective of increasing their corporate reputation but without any incentive to implement the 10 principles [84]. Future studies should be performed with the objective of examining not only the firm's affiliation with the Global Compact, but also the level of implementation of each principle and the initiatives performed related to the affiliation. Another limitation of this study was that although the use of an international sample of analysis appears to be a strong aspect, the sample bias towards the United States of America, United Kingdom, and Japan should be emphasized, as those countries were over-represented in the sample. The analysis could be performed in a more balanced sample with a greater representation of the countries examined. Moreover, the results suggest that there are differences in the affiliation of firms with the United Nations Global Compact by country. Therefore, future studies could examine whether the results can be generalized to all regions with similar institutional factors (such as gross domestic product, culture, national responsibility to social and environmental issues). Since firms operating in each industry are likely to be influenced by mimetic pressures, future studies could also examine whether the results can be generalized for all industries or whether there are differences in different sectors (e.g., oil, gas, and consumable fuels vs. financial sector).

Author Contributions: Conceptualization: J.M.-F., M.E., and N.C.; methodology, software, formal analysis: J.M.-F.; writing — original draft preparation, M.E. and N.C.; writing—review and editing: J.M.-F. All authors have read and agreed to the published version of the manuscript.

Funding: This research received no external funding.

Conflicts of Interest: The authors declare no conflict of interest.

\section{References}

1. Cetindamar, D.; Husoy, K. Corporate social responsibility practices and environmentally responsible behavior: The case of United Nations Global Compact. J. Bus. Ethics 2007, 76, 163-176. [CrossRef]

2. Janney, J.J.; Dess, G.; Forlani, V. Glass houses? Market reactions to firms joining the UN Global Compact. J. Bus. Ethics 2009, 90, 407-423. [CrossRef]

3. Kimbro, M.B.; Cao, Z. Does voluntary corporate citizenship pay? An examination of the UN Global Compact. Int. J. Account. Inf. Manag. 2011, 19, 288-303. [CrossRef]

4. Rasche, A.; Waddock, S.; McIntosh, M. The United Nations Global Compact: Retrospect and prospect. Bus. Soc. 2012, 52, 6-30. [CrossRef]

5. Amer, E. The penalization of non-commuting UN Global Compact's companies by investors and its implications for this initiative's effectiveness. Bus. Soc. 2018, 57, 255-291. [CrossRef]

6. Orzes, G.; Moretto, A.M.; Moro, M.; Rossi, M.; Sartor, M.; Caniato, F.; Nassimbeni, G. The Impact of the United Nations Global Compact on firm performance: A longitudinal analysis. Int. J. Prod. Econ. 2020. [CrossRef]

7. Rasche, A. The United Nations Global Compact and the sustainable development goals. In Research Handbook of Responsible Management; Laasch, O., Jamali, D., Freeman, R.E., Suddaby, R., Eds.; Edward Elgar Publishing: Trotterham, UK, 2020. 
8. Arévalo, J.A.; Aravind, D.; Ayuso, S.; Roca, M. The Global Compact: An analysis of the motivations of adoption in the Spanish Context. Bus. Ethics 2013, 22, 12005.

9. Arévalo, J.A.; Aravind, D. The impact of the crisis on corporate responsibility: The case of UN Global Compact participants in the USA. Corp. Gov. 2010, 10, 406-420. [CrossRef]

10. Orzes, G.; Moretto, A.M.; Ebrahimpour, M.; Sartor, M.; Moro, M.; Rossi, M. United Nations Global Compact: Literature review and theory-based research agenda. J. Clean. Prod. 2018. [CrossRef]

11. Ayuso, S.; Roca, M.; Arévalo, J.A.; Aravind, D. What determines principle-based standards implementation? Reporting on Global Compact adoption in Spanish firms. J. Bus. Ethics 2016, 133, 535-565. [CrossRef]

12. Schembera, S. Implementing corporate social responsibility: Empirical insights on the impact of the UN Global Compact on its business participants. Bus. Soc. 2018, 57, 783-825. [CrossRef]

13. Bremer, J.A. How global is the Global Compact? Bus. Ethics 2008, 17, 223-244. [CrossRef]

14. Bernhagen, P.; Mitchell, N.J.; Thissen-Smits, M. Corporate citizens and the UN Global Compact: Explaining cross-national variations in turnout. Bus. Polit. 2013, 15, 63-85. [CrossRef]

15. Pérez-Batres, L.A.; Miller, V.V.; Pisani, M.J. CSR, sustainability and the meaning of global reporting for Latin American corporations. J. Bus. Ethics 2010, 91, 193-209. [CrossRef]

16. Arévalo, J.A.; Aravind, D. Strategic outcomes in voluntary CSR: Reporting economic and reputational benefits in principles-based initiatives. J. Bus. Ethics 2017, 144, 201-217. [CrossRef]

17. Sulkowski, A.J.; Edwards, M.; Freeman, R. Shake your stakeholder: Firm initiated interactions to create shared sustainable value. Organ. Environ. 2018, 31, 223-241. [CrossRef]

18. Galbreath, J. Are there gender-related influences on corporate sustainability? A study of women on boards of directors. J. Manag. Organ. 2011, 17, 17-38. [CrossRef]

19. Zhang, L. Board demographic diversity, independence, and corporate social performance. Corp. Gov. 2012, 12, 686-700. [CrossRef]

20. del Carmen Valls Martínez, M.; Cruz Rambaud, S.; Parra Oller, I.M. Gender policies on board of directors and sustainable development. Corp. Soc. Responsib. Environ. Manag. 2019, 26, 1539-1553.

21. Liao, L.; Luo, L.; Tang, Q. Gender diversity, board independence, environmental committee and greenhouse gas disclosure. Br. Account. Rev. 2015, 47, 409-424. [CrossRef]

22. Ben-Amar, W.; Chang, M.; McIlkenny, P. Board gender diversity and corporate response to sustainability initiatives: Evidence from the carbon disclosure project. J. Bus. Ethics 2017, 142, 369-383. [CrossRef]

23. Issa, A.; Fang, H. The impact of board gender diversity on corporate social responsibility in the Arab Gulf States. Gend. Manag. 2019, 34, 577-605. [CrossRef]

24. Eberhardt-Toth, E.; Caby, J.; Gendron, C.; Ramboarisata, L. Determinants of the presence of CSR committees within European boards of directors. E. Responsib. Organ. Rev. 2019, 14, 33-49. [CrossRef]

25. Amran, A.; Lee, S.P.; Devi, S.S. The influence of governance structure and strategic corporate social responsibility toward sustainability reporting quality. Bus. Strategy Environ. 2014, 23, 217-235. [CrossRef]

26. Ashfaq, K.; Rui, Z. Revisiting the relationship between corporate governance and corporate social and environmental disclosure practices in Pakistan. Soc. Responsib. J. 2018, 15, 90-119. [CrossRef]

27. Baraibar-Diez, E.; Odriozola, M.D. CSR committees and their effect on ESG performance in UK, France, Germany and Spain. Sustainability 2019, 11, 5077. [CrossRef]

28. Cucari, N.; de Falco, S.E.; Orlando, B. Diversity of board of directors and environmental social governance: Evidence from Italian listed companies. Corp. Soc. Res. Environ. Manag. 2017, 25, 250-266. [CrossRef]

29. Eberhardt-Toth, E. Who should be on a board corporate social responsibility committee? J. Clean. Prod. 2017, 140, 1926-1935. [CrossRef]

30. García-Sánchez, I.M.; Gomez-Miranda, M.; David, F.; Rodríguez-Ariza, L. The explanatory effect of CSR committee and assurance services on the adoption of the IFC performance standards, as a means of enhancing corporate transparency. Sustain. Account. Manag. Policy J. 2019, 10, 773-797. [CrossRef]

31. Helfaya, A.; Moussa, T. Do board's corporate social responsibility strategy and orientation influence environmental sustainability disclosure? UK Evidence. Bus. Strategy Environ. 2017, 26, 1061-1077. [CrossRef]

32. Gennari, F. How to lead the board of directors to a sustainable development of business with the CSR committees. Sustainability 2019, 11, 6987. [CrossRef]

33. Gennari, F.; Salvioni, D.M. CSR committees on boards: The impact of the external country level factors. J. Manag. Gov. 2019, 23, 759-785. [CrossRef] 
34. Haque, F.; Jones, M.J. European firms' corporate biodiversity disclosures and board gender diversity from 2002 to 2016. Br. Account. Rev. 2020, 100893. [CrossRef]

35. Coulmont, M.; Berthelot, S.; Paul, M. The Global Compact and its concrete effects. J. Glob. Responsib. 2017, 8, 300-311. [CrossRef]

36. Kilic, M.; Kuzey, C. The effect of corporate governance on carbon emission disclosures: Evidence from Turkey. Int. J. Clim. Chang. Strat. Manag. 2019, 11, 35-53. [CrossRef]

37. Aragon-Correa, J.A.; Marcus, A.A.; Vogel, D. The effects of mandatory and voluntary regulatory pressures on firms' environmental strategies: A review and recommendations for future research. Acad. Manag. Ann. 2018, 14. [CrossRef]

38. Waddock, S. Building a new institutional infrastructure for corporate responsibility. Acad. Manag. Perspect. 2008, 22, 87-108. [CrossRef]

39. Kell, G. The Global Compact: Origins, operations, progress, challenges. J. Corp. Citiz. 2003, 11, 35-49.

40. United Nations Global Compact, The Ten Principles of the UN Global Compact. Available online: https: //www.unglobalcompact.org/what-is-gc/mission/principles (accessed on 10 April 2020).

41. Williams, O.F. The United Nations Global Compact: What did it promise? J. Bus. Ethics 2014, 122, $241-251$. [CrossRef]

42. Kell, G.; Slaughter, A.; Hale, T. Silent reform through the Global Compact. UN Chron. 2007, 44, $26-31$.

43. Fritsch, S. The UN Global Compact and the global governance of corporate social responsibility: Complex multilateralism for a more human globalisation? Glob. Soc. 2008, 22, 1-26. [CrossRef]

44. Berliner, D.; Prakash, A. The United Nations Global Compact: An institutionalist perspective. J. Bus. Ethics 2014, 122, 217-223. [CrossRef]

45. United Nations Global Compact, Our Participants. 2020. Available online: https://www.unglobalcompact.org/ what-is-gc/participants/search?utf8=\%E2\%9C\%93\&search $\% 5$ Bkeywords $\% 5 \mathrm{D}=\&$ search $\% 5 \mathrm{Bcountries} \%$ 5D\%5B\%5D=95\&search\%5Bper_page \%5D=10\&search\%5Bsort_field \%5D=\&search\%5Bsort_direction\% $5 \mathrm{D}=$ asc (accessed on 10 April 2020).

46. Sethi, S.P.; Schepers, D.H. United Nations Global Compact: The promise-performance gap. J. Bus. Ethics 2014, 122, 193-208. [CrossRef]

47. Brown, J.A.; Clark, C.; Buono, A.F. The United Nations Global Compact: Engaging implicit and explicit CSR for global governance. J. Bus. Ethics 2018, 147, 721-734. [CrossRef]

48. Abdelzaher, D.; Fernandez, W.D.; Schneper, W.D. Legal rights, national culture and social networks: Exploring the uneven adoption of United Nations Global Compact. Int. Bus. Rev. 2019, 28, 12-24. [CrossRef]

49. Garayar, A.; Heras-Saizarbitoria, I.; Boiral, O. Adoption of the UN Global Compact in Spanish banking: A case study. J. Public Aff. 2016, 16, 359-367. [CrossRef]

50. Berliner, D.; Prakash, A. "Bluewashing" the firm? Voluntary regulations, program design, and member compliance with the United Nations Global Compact. Policy Stud. J. 2015, 43, 115-138. [CrossRef]

51. Vogler, D.; Eisenegger, M. Corporate scandals as a denial of reputation. In The Routledge Companion to Media and Scandals; Tumber, H., Waisbord, S., Eds.; Routledge: London, UK, 2019.

52. Kılıç, M.; Kuzey, C. The effect of board gender diversity on firm performance. Gend. Manag. 2016, 31, 431-455.

53. Boulouta, I. Hidden connections: The link between board gender diversity and corporate social performance. J. Bus. Ethics 2013, 113, 185-197. [CrossRef]

54. Shrader, C.B.; Blackburn, V.B.; Iles, P. Women in management and firm financial management. J. Manag. Issues 1997, 9, 355-372.

55. Dobbin, F.; Jung, J. Corporate board gender diversity and stock performance: The competence gap or institutional investor bias. NCL Rev. 2011, 89, 809-840.

56. Lenard, M.J.; Yu, B.; York, E.A.; Wu, S. Impact of board gender diversity on firm risk. Manag. Financ. 2014, 40, 787-803. [CrossRef]

57. Chen, J.; Leung, W.S.; Evans, K.P. Female board representation, corporate innovation and firm performance. J. Empir. Financ. 2018, 48, 236-254. [CrossRef]

58. E-Vahdati, S.; Zulkifli, N.; Zakaria, Z. A moderated mediation model for board diversity and corporate performance in ASEAN countries. Sustainability 2018, 10, 556. [CrossRef] 
59. Slama, R.B.; Ajina, A.; Lakhal, F. Board gender diversity and firm financial performance in France: Empirical evidence using quantile difference-in differences and dose response models. Cogent Econ. Financ. 2019, 7, 1626526 .

60. Bernardi, R.A.; Bosco, S.M.; Vassill, K.M. Does female representation on board of directors associate with Fortune's "100 Best Companies Work For" list? Bus. Soc. 2006, 45, 235-248. [CrossRef]

61. Bernardi, R.A.; Bosco, S.M.; Columb, V.L. Does female representation on boards of directors associate with the 'Most Ethical Companies' list? Corp. Reput. Rev. 2010, 12, 270-280. [CrossRef]

62. Ararat, M.; Sayedy, B. Gender and climate change disclosure: An interdimensional policy approach. Sustainability 2019, 11, 7217. [CrossRef]

63. Williams, R.J. Women on corporate boards of directors and their influence on corporate philanthropy. J. Bus. Ethics 2003, 42, 1-10. [CrossRef]

64. Pope, S.; Wæraas, A. CSR-washing is rare: A conceptual framework, literature review and critique. J. Bus. Ethics 2016, 137, 173-193. [CrossRef]

65. Monteduro, F.; Hinna, A.; Ferrari, R. The board of directors and the adoption of quality management tools. Public Manag. Rev. 2011, 13, 803-824. [CrossRef]

66. Hendry, K.; Kiel, G. The role of the board in firm strategy: Integrating agency and organizational control perspectives. Corp. Gov. 2004, 12, 500-520. [CrossRef]

67. Jain, T.; Zaman, R. When boards matter: The case of corporate social irresponsibility. Br. J. Manag. 2019, 31, 365-386. [CrossRef]

68. Carroll, A.B. Corporate social responsibility: Evolution of a definitional construct. Bus. Soc. 1999, 38, 268-295. [CrossRef]

69. Wells, P.; Ingley, C. Interlocking directorships and the corporate-community connection: Evidence from the Antipodes. In Proceedings of the 11th European Conference on Management Leadership and Governance, Military Academy, Lisbon, Portugal, 12-13 November 2015; Academic Conferences and Publishing International Limited. pp. 523-531.

70. Yunus, S.; Evangeline, E.T.; Abhayawansa, S. Determinants of carbon management strategy adoption: Evidence from Australia's top 200 publicly listed firms. Manag. Audit. J. 2016, 31, 156-179. [CrossRef]

71. del Valle, I.D.; José María Díez Esteban, J.M.D.; de Foronda Pérez, O.L. Corporate social responsibility and sustainability committee inside the board. Eur. J. Int. Manag. 2019, 13, 159-176. [CrossRef]

72. Salvioni, D.M.; Gennari, F. Stakeholder perspective of corporate governance and CSR committees. Symph. Emerg. Issues Manag. 2019, 1, 28-39. [CrossRef]

73. Tingbani, I.; Chithambo, L.; Tauringana, V.; Papanikolaou, N. Board gender diversity, environmental committee and greenhouse gas voluntary disclosures. Bus. Strategy Environ. 2020, 1-17. [CrossRef]

74. Brindelli, G.; Dell'Atti, S.; Iannuzzi, P.A.; Savioli, M. Composition and activity of the board of directors: Impact on ESG performance in the banking system. Sustainability 2018, 10, 4699. [CrossRef]

75. Baron, R.M.; Kenny, D.A. The moderator-mediator variable distinction in social psychological research: Conceptual, strategic, and statistical considerations. J. Personal. Soc. Psychol. 1986, 51, 1173-1182. [CrossRef]

76. Ortas, E.; Álvarez, I.; Garayar, A. The environmental, social, governance, and financial performance effects on companies that adopt the United Nations Global Compact. Sustainability 2015, 7, 1932-1956. [CrossRef]

77. Bernardi, R.A.; Threadgill, V.H. Women directors and corporate social responsibility. Electron. J. Bus. Ethics Organ. Stud. 2010, 15, 15-21.

78. Seto-Pamies, D. The relationship between women directors and corporate social responsibility. Corp. Soc. Responsib. Environ. Manag. 2015, 22, 334-345. [CrossRef]

79. Godos-Díez, J.L.; Cabeza-García, L.; Alonso-Martínez, D.; Fernández-Gago, R. Factors influencing board of directors' decision-making process as determinants of CSR engagement. Rev. Manag. Sci. 2018, 12, 229-253. [CrossRef]

80. El Ghoul, S.; Guedhami, O.; Nash, R.; Patel, A. New evidence on the role of the media in corporate social responsibility. J. Bus. Ethics 2019, 154, 1051-1079. [CrossRef]

81. Colakoglu, N.; Eryilmaz, M.; Martínez-Ferrero, J. Is board diversity an antecedent of corporate social responsibility performance in firms? A research on the 500 biggest Turkish companies. Soc. Responsib. J. 2020. [CrossRef]

82. Martínez-Ferrero, J.; García-Sánchez, I.M. Coercive, normative and mimetic isomorphism as determinants of the voluntary assurance of sustainability reports. Int. Bus. Rev. 2017, 26, 102-118. [CrossRef] 
83. Rasche, A. "A necessary supplement" what the United Nations Global Compact is and is not. Bus. Soc. 2009, 48, 511-537. [CrossRef]

84. Deva, S. Global Compact: A Critique of the UN's public-private partnership for promoting corporate citizenship. Syracuse J. Int'l L. Com. 2006, 34, 107.

(C) 2020 by the authors. Licensee MDPI, Basel, Switzerland. This article is an open access article distributed under the terms and conditions of the Creative Commons Attribution (CC BY) license (http://creativecommons.org/licenses/by/4.0/). 